\title{
The implementation of migration policy in Ukraine: autonomous or directed?
}

\begin{abstract}
This article focuses on the Ukraine as a major transit route to EU countries. The author argues that EU policy has attempted to make Ukraine into a 'safe third country' by delegating questions of migration control and border protection. However, by not ensuring that the measures are properly embedded, the policy is failing both the EU and Ukraine in leaving domestic policy geared apparently to the cause of international interests and implicating a lack of domestic ownership and weak and paralysed institutions. The author is also critical of the approach to refugee policy within Ukraine, which has been damaged both by political sclerosis, stalled reforms and a plethora of domestic organisations, departments and responsibilities resulting from a lack of political will. This has left domestic policy vulnerable to the EU in policy terms and implementation in the hands of donor-driven international migration organisations. The author concludes that Ukraine is unable to cope with its societal and political consequences in this area or fulfil its international obligations, and that the situation facing migrants remains precarious.
\end{abstract}

Keywords: migration, border control, securitisation, re-admission, refugees, asylum seekers, EU resourcing, NGOs, detention camps, institutional racism, xenophobia, hate crime.

\section{Introduction}

Images of people trying to reach the European Union (EU) by crossing the Mediterranean Sea have been broadcast quite extensively in the media, provoking both a public and a political response. In contrast, another major route for migrants and refugees to the EU receives rather less media attention: a large number of refugees and migrants attempt to enter the EU through Ukrainian territory, seeking to cross the border between Ukraine and either Slovakia, Hungary or Poland. The most important routes for irregular migrants and refugees lead from South Asia and Africa through the post-Soviet space to the EU. In addition, there are routes for migrants from the former Soviet Union itself.

Following the EU enlargements in 2004 and 2007, Ukraine now shares a $1400 \mathrm{~km}$ long border with the EU and has thus gained special importance as regards the European migration system and the EU border regime. Due to its strategic geographic location, its essentially unsecured border with Russia, visa-free travel for citizens of CIS states and a lack of effective readmission agreements, as well as insufficient law enforcement, Ukraine has become a transit and buffer zone for various migration flows towards the EU as well as a destination country of second choice for asylum seekers and migrants. 
Throughout this article, I argue that the European Union has negligently assigned Ukraine the task of dealing with refugees and migrants who are stranded in Ukraine on their way to the EU. The EU has sought to create a policy field from the outside via political and financial conditionality measures and by attempting to turn Ukraine into a 'safe third country'. The measures are not embedded in and, therefore, are remote from Ukrainian reality; the EU has created Potemkin villages, ${ }^{1}$ which it then deliberately mistakes for reality.

Relations between the EU and its neighbours are largely determined by questions of security, reflecting the wide understanding of security prevalent in the EU, including economic and social security. Thus, one might define the relationship between the wellto-do core of the EU and its periphery - including Ukraine - as a 'political deal' (Vobruba, 2007: 9) with the aim of safeguarding intra-EU security. The core considers the periphery as a source of both economic and political conflict, as well as a protective zone, i.e. as both a problem and a solution in combating illegal ${ }^{2}$ migration and transnational crime. To this end, the EU has assigned Ukraine the tasks of exclusion (Vobruba, 2007: 10-11), especially concerning questions of migration control and border protection. The principles of safe third countries and safe country of origin systematically encompass Ukraine within the EU asylum regime (Knelangen, 2007: 263). ${ }^{3}$

In practical terms, the Ukrainian authorities protect the EU's eastern border, control their own territory and either readmit undocumented migrants or else prevent them from reaching the EU. At the same time, Ukraine has requested reciprocity in financial and political terms (Knelangen, 2007: 268). A general EU-Ukraine readmission agreement has been concluded in exchange for the greater facilitation of bilateral visas for Ukrainian citizens and for further support with economic and political reforms. The readmission agreement entered into force in 2008 and concerns all those who have been apprehended as 'illegal' migrants in the EU (both Ukrainian and third country nationals), having crossed Ukrainian territory on the way (Kokhan, 2007: 2). ${ }^{4}$ In 2008, the EU provided $€ 30 \mathrm{~m}$ to Ukraine to readmit migrants.

Moreover, various instruments, programmes and funding have been devised to enable Ukraine to accept refugees according to the specifications of the Geneva Convention Relating to the Status of Refugees (1951) - and thus it no longer serves only as a transit state. ${ }^{5}$ Not surprisingly, most EU funds dedicated to migration issues have been spent on the enhancement of border protection. In this context, Ukraine has concluded

1 Russian minister Grigorii Potemkin is said to have built these façades on Ukrainian territory in the $18^{\text {th }}$ century to impress Empress Katarina II.

2 Official UN terminology uses 'irregular migration' and 'irregular migrant', or 'undocumented migrant or alien', rather than 'illegal migration/migrant'. The latter is used in national legislation and regulations in the EU and emphasises the interests of the state, while the former stresses migrants' human rights (ICPS/IPA, 2006).

3 Details on this issue are provided by Vobruba (2007) and Knelangen (2007).

4 Ukraine does not benefit from the agreement since there are virtually no EU citizens or people crossing the EU who enter Ukraine illegally. Due to a lack of functioning readmission agreements with other countries, it is likely that readmitted third country nationals will remain in Ukraine (ICPS, 2005; Speer, 2010).

5 An overview is provided by Geiger (2007) and Zimmer (2009). 
a working agreement with the European Agency for the Management of Operational Co-operation at External Borders, FRONTEX. ${ }^{6}$ Activities are mostly aimed at improving co-operation among troops on Ukraine's various borders with the EU.

\section{Transit migration and immigration to Ukraine}

Many transit migrants originate from countries whose citizens may enter Ukraine without a visa and only violate the law when they attempt to cross Ukraine's western border. For others, the very stay in Ukraine is 'illegal': in particular, Chinese, Vietnamese, Indians, Iranians, Pakistani, Tamils, Iraqis, Afghans, Kurds and Palestinians, as well as Somalis, west Africans and Egyptians, but also Belarusians, Georgians, Moldovans and citizens from other CIS states, use Ukraine as a transit country.

The size, composition and legal status of immigrant groups in Ukraine have all changed fundamentally since 1991 . During the Soviet era, migrants mainly arrived on the basis of study and labour agreements with other socialist countries. They had secure status based on residential permits and regular incomes. At the beginning of the 1990s, the Ukrainian state rather generously accepted refugees who fled ethnic conflicts in the former Soviet Union. Later, the number of migrants and refugees from outside the post-Soviet space increased, especially from Afghanistan, many of whom have been granted asylum.

Many new arrivals, however, are not refugees according to the definition of the Geneva Refugee Convention, but remain in Ukraine without applying for refugee status because they cannot pass across the EU border. For others, the administrative barriers to successful applications are too great. Additionally, many people from the former Soviet Union enter Ukraine on a visa-free basis (for up to ninety days), or on a student, business or tourist visa, but become 'illegal' by over-staying. ${ }^{7}$ For many migrants, not only is access to EU territory blocked, but also the way back to their countries of origin. Thus, Ukraine involuntarily turns into a destination country for migrants (Knelangen, 2007: 269), many of whom do not have secure residential permit status.

In 2000, the Ukrainian Ministry of the Interior estimated that between 20000 and 30000 undocumented migrants were living in Ukraine; other organisations, however, put the number much higher, at 500000 to one million. Three years later, the numbers were still contradictory. The United Nations estimated that up to six million undocumented migrants were residing in Ukraine in 2003 (Uehling, 2004). From 1991 to 2003, the Ukrainian Border Guards arrested more than 91000 people, while the Ministry of the Interior detained about 10000 people between 2001 and 2003. ${ }^{8}$ In 2007, the Border Guards detained 36000 people - a rise of more than 100 per cent compared to 2005 (Söderköping Process, 2008b). Presumably, the number of people who successfully cross the EU border is two to ten times higher. Among the arrested, the number of CIS

6 More information on FRONTEX can be found here: http://www.frontex.europa.eu [last accessed 22 January 2011].

7 So far, Ukraine has not implemented the stricter visa regulations demanded by the EU.

8 The Ministry of the Interior is responsible for searching for irregular migrants on Ukrainian territory, while the State Border Guards detain illegal border crossers and decide on the expulsion of foreigners and stateless people (Pribytkova, 2007). 
citizens has been rising, currently making up about sixty per cent. During the last decade, more than ninety per cent of the ensuing deportations took place to Russia (Oliynyk, 2006).

\section{Ukrainian refugee policy}

The Ukrainian government passed its first refugee ${ }^{9}$ law in 1993, but implementation only started in 1996. In the second half of the 1990s, reforms stalled; in 2002, Ukraine ratified the Geneva Refugee Convention and became a member of the International Organisation for Migration (IOM). A new refugee law was passed in 2003 and reformed in 2005; yet, the legal framework does not entirely conform with international norms as refugee status is not complemented by subsidiary or humanitarian protection. The parliament has, since 2007, been expected to pass a new law introducing the required changes but, due to the continuing political crisis, this project has been put on the backburner. However, as we will see below, even the implementation of the laws which are operational is inadequate.

Ukraine lacks a central authority dealing comprehensively with migration issues (UNHCR, 2007). Despite several attempts at reform, refugee and asylum policy continue to be characterised by conflicting, overlapping and lacking competencies, as well as a lack of funds and never-ending reforms. The State Committee responsible for migration and refugee questions has been reorganised eleven times since 1996 (Amnesty International, 2010: 6). It co-ordinates its activities with the ministry of Foreign Affairs, as well as with the Interior, Labour and Social Policy and Health Policy ministries, and with the State Border Guards, but the degree of effective co-operation is poor (Hammarberg, 2006: 26). The State Committee deals with legal migration, including the recognition of refugees, whereas the Ministry of the Interior and the State Border Guards are concerned with the regulation and prevention of irregular migration (Pribytkova, 2007). In 2008 and 2009, the government sought on several occasions to transfer responsibility for refugee and asylum affairs to the Ministry of Internal Affairs. However, the President repeatedly vetoed this decision (Amnesty International, 2010; Kotnyuk, 2008; Ryzhuk, 2009), accusing the government of violating the Constitution. Obviously, the material interests of various authorities played a decisive role in this conflict since Ukraine expects greater funding from the EU in this policy field.

According to international and Ukrainian law, no action may be brought against people who enter the country illegally as long as they intend to apply for asylum. During the asylum procedure, expulsions are prohibited. People who apply for asylum are normally released from custody and obtain identity cards. If migrants are arrested and apply for asylum, the Border Guards and the Ministry of the Interior are obliged to forward their application within 24 hours. However, not all migrants have the possi-

9 According to Ukrainian law, a refugee is a person who is not a citizen of Ukraine and who, due to reasonable fear of persecution on the basis of race, religion, nationality, membership of a particular social group or the possession of a political opinion, resides outside his country of origin and cannot return there. The same applies to stateless people. Furthermore, the situation of asylum seekers and migrants is regulated by the Law on the Legal Status of Foreign Citizens and Stateless People, the Ukrainian Constitution and various administrative regulations. 
bility of filing an application, often due to ignorance and insufficient funding at the regional level.

Those who have the chance of applying for asylum are faced with the following legal procedure. The responsible State Committee for Nationalities and Religion is a central state authority with its headquarters in Kyiv and it is this body which determines the granting of refugee status and which must substantiate rejections. Migration services in 24 Ukrainian regions, established in 2006, carry out initial questioning and accept applications. On the basis of documents and questioning, the respective officials decide whether to pass on the application to the State Committee in Kyiv for a decision. If applications are rejected, applicants can appeal, namely to the State Committee (within one month) or to the court (within one year). If the State Committee rejects the application once more, the applicants can take legal action. After a final rejection in all instances, deportation is pending. However, the Ukrainian state lacks resources for deportations and many rejected asylum seekers go into hiding.

Both the inadequate funding and the staffing of the responsible authorities have adverse effects on the adequacy of the asylum procedures. In 2007, the migration service in Transcarpathia lacked, for example, elementary equipment such as paper, a computer or a camera for taking pictures of asylum seekers. ${ }^{10}$ Low salaries lead to high staff turnover and vacancies, which hamper the continuing and smooth co-operation with other organisations. In 2007, the migration service in Kyiv employed only three people who accepted documents and carried out initial interviews, ${ }^{11}$ which led to threemonth waiting periods for an appointment. In 2002, 2006 and in 2007, the State Committee temporarily stopped working so that no applications were processed at all (Andrysek and Rantala, 2008; Pribytkova, 2007: 7); while, in 2009, the fight over responsibilities led to further disruptions. Without valid documents, applicants are breaking the law and can be stopped on the street at any time.

Formal responsibility for migration and asylum policy lies with the Ukrainian authorities, but international governmental organisations (IGOs) and Ukrainian non-governmental organisations (NGOs) play a decisive role. The latter assume genuine state tasks, such as the provision of the humanitarian support and legal advice for detainees and applicants which is required by law. However, without the financial and technical support of international and supranational organisations, these NGOs would cease to exist. In the context of political exchange, international donors compensate for the financial weakness and the lacking political will of the Ukrainian state. The most important international organisations are the UNHCR, the IOM and the Delegation of the EU Commission, all of which have offices in central Kyiv. The IOM has been present in Ukraine since 1996 and is assisting the Ukrainian authorities with the development of a migration management system and the harmonisation of national law with EU law. Furthermore, it deals with the control of irregular migration movements and also supports the State Border Guards. The UNHCR supports and consults the Ukrainian government with regard to legislation and monitors the implementation of the Geneva Refugee Convention.

10 Interview with a representative of NEEKA, held in Mukachevo on 1 June 2007.

11 Interview with a representative of HIAS, Kyiv, held on 7 June 2007. 
Not only does the EU exert strong influence on legislation - it is also the main donor in this policy field. Most EU money, however, is not targeted directly towards the Ukrainian government but is spent on measures implemented by IGOs, especially the IOM (Geiger, 2007: 65-67). With their projects, the EU, the UNHCR and the IOM finance almost all activities directed at asylum seekers and refugees in Ukraine and assume various co-ordination tasks. The EU capitalises on the expertise and experience of these agencies and, in the case of UNHCR, its role and reputation in protecting refugees and human rights, immunising itself to criticism. Geiger (2007: 76) therefore labels IGOs as the 'transmission belts' of EU policy. Both the IOM and UNHCR collaborate with several local implementing partners: UNHCR, for example, co-operates with and supports NEEKA and Caritas in Mukachevo (Transcarpathia); the South Ukrainian Centre of Young Lawyers (SUCYL) in Odesa; and HIAS (Hebrew Immigrant Aid Society) in Kyiv. NEEKA mainly offers social support for refugees and asylum seekers; while Caritas, as well as HIAS and SUCYL, consult asylum seekers regarding applications for refugee status and represent them at authorities and in court. $^{12}$

It is apparent that the activities of Ukrainian NGOs, funded by the IGOs, are indispensable to creating the very social and organisational preconditions for the initiation of asylum procedures. In the medium term, the EU is thus turning Ukraine into the desired 'safe third country'.

\section{Problems of refugees in Ukraine}

Asylum seekers who would like to remain in Ukraine mostly live in the cities, where they can find work more easily and rely on established (ethnic) networks. Those who want to cross the EU border typically stay in Transcarpathia, where approximately half of all asylum applications are filed. Most applicants are arrested while attempting to cross the border illegally and are taken to regional detention camps.

Until recently, the detention camps, which are subordinate to the State Border Guards, were characterised by overcrowding, decay and bad hygienic conditions, as well as a lack of food. ${ }^{13}$ The camp for men in Pavshino, for example, close to Mukachevo near the Hungarian and Slovak borders, has a capacity of 200 people; yet, in the summer up to 700 men - mainly from Asia and Africa - were detained there. When a report by Human Rights Watch (2005) disclosed the conditions in the camp, increasing pressure from foreign NGOs and governments led to the partial improvement of the situation, while the operation of the camp was officially terminated in September 2008. The detainees were partly relocated to newly-built camps in Volyn and Chernihiv regions (www.dw-world.de, 24 October 2008). In addition, there is special accommodation for women and children with fifty places, which is mostly overcrowded. In the city of Chop on the Hungarian border, migrants from the CIS are detained in a prison. Deportations from the prison primarily concern Chechens, who are sent back to Russia. Often, local NGOs do not gain access to the camps to fulfil their tasks of social and 
legal protection. Moreover, Ukraine has forcibly returned asylum seekers and even recognised refugees to countries where they are at risk of being maltreated, for example in Uzbekistan or Sri Lanka (Amnesty International, 2010: 8).

More than 5000 asylum seekers, of whom 2275 were still living in Ukraine in early 2007, have been granted protection since 1996. In addition, 800 to 900 people have become Ukrainian citizens. In early 2007, 3000 asylum seekers were registered. Every year, 1000 to 1500 people apply for asylum. Most refugees were recognised from 1997 to 2001, whereas only 296 people were recognised between 2002 and 2007. Up to 2001 , the recognition rate was about fifty per cent; presently, it is 2.5 to 3 per cent and has thus reached 'normal' EU levels. In the years since 1996, fifty per cent of applicants have come from Afghanistan, 30 to 35 per cent from CIS states and about 10 per cent from Africa. The structure of accepted refugees looks similar. In addition, Ukraine hosts refugees from Iraq, Syria and Iran (Söderköping Process, 2008a).

Around one-half of recognised refugees are registered in Kyiv ${ }^{14}$ and 25 per cent in Odesa, while the rest reside in other major cities. Refugees must renew their status every year. According to the law, they enjoy to a large extent the same rights as Ukrainian citizens, including freedom of movement and residence, and the right to education, medical care, family reunification, marriage, work, business activity and social and legal support. However, their actual integration into Ukrainian society is problematic. Many legally-guaranteed services and benefits for asylum seekers and refugees are not granted. The Ukrainian state supports refugees neither financially nor with language courses nor special integration programmes. There is only a single staterun accommodation for asylum seekers (in a suburb of Odesa), which was substantially financed by the EU (Andrysek and Rantala, 2008), although others are currently being built or planned.

\section{Xenophobia and racism}

A recent increase in hate crimes (ranging from vandalism to murder) against migrants, foreign students and asylum seekers has alarmed international organisations and human rights activists (Zimmer, 2010). ${ }^{15}$

The Ukrainian population has little information about the issue of, and the situation faced by, refugees. Foreigners are perceived as a source of violence, chaos and illness and increasingly serve as scapegoats for social problems. Sometimes, reports on undocumented immigration are published in the media - almost exclusively with a negative bias. It is normally interpreted as a crime to which one has to react with repressive measures. The public discourse on immigration is thus characterised by securitisation

14 A detailed study of 'non-traditional' immigrants has been submitted by Braichevska et al. (2004).

15 International organisations and foreign, as well as some Ukrainian, NGOs have reported on hate crimes since 2005. Most of the victims are Roma and Jews. However, the number of crimes committed against students, refugees and migrants from Asia and Africa has increased. 
(Zimmer, 2007). Moreover, some newspaper articles associate 'illegal' migrants with a rise in crime rates (Pylynskyi, 2008). ${ }^{16}$

Moreover, state authorities at times act in a discriminatory way. Racial profiling is widespread, i.e. people with dark skin are disproportionally often subject to identity checks, including people from the Caucasus, mainly from Georgia and Armenia. Officially, these checks serve to combat illegal migration but they can also lead to arbitrary arrest and to corruption (Coynash, 2008; Manukjan, 2008). Often, police officers are not familiar with the documents of asylum seekers or recognised refugees (Amnesty International, 2008: 31). Victims are normally afraid to report crimes because the police also tend to act in a racist way, while maltreatment in police custody has been reported (Amnesty International, 2008: 29). International organisations and Ukrainian NGOs are critical of the police service for its low level of sensitivity and experience in dealing with ethnic minorities, and have recommended awareness training (Human Rights First, 2008: 1).

On the whole, the situation stabilised in 2009 , when the number of racially-motivated crimes declined. International organisations and Ukrainian experts, however, caution of the need not to speak of a reversal of the trend, because the decline is not linear. Moreover, the number of attacks on homosexuals and anti-fascists seems to be on the rise (Lihachev, 2010).

Up to 2008, it was only the international organisations that perceived the growing number of obviously racially-motivated crimes to be a problem, whereas the Ukrainian political elite continued to cultivate the image of a tolerant society. Racist attacks on diplomats and the persistent pressure of international organisations, however, compelled the government to act. The government and other state authorities have, since late 2007, initiated a number of measures and activities. Many ministries and law enforcement authorities have established special departments or envoys which have devised plans to combat racism and xenophobia. Initially, the measures did not envisage preventive components (Zimmer, 2010). Moreover, law enforcement remains problematic. Two relevant articles in the Criminal Code which refer specifically to racist motivations (Articles 161 and 67) are hardly ever applied. Instead, many racist crimes are prosecuted as 'hooliganism'. Legal changes in the Criminal Code dating from November 2009 have not yet yielded results. When the Ministry of the Interior established a unit for 'ethnic crime', the head assumed that he would have to spent most of his time investigating crimes committed by foreigners; in February 2008, however, he reported spending about eighty per cent of his time solving crimes committed against foreigners. Yet, until 2009, the authorities only registered crimes committed crimes by foreigners (Amnesty International, 2008: 11). Most authorities (mainly the police and the secret service) focus on protecting embassies and dormitories for foreign students and on fighting right-wing groups, mainly skinheads (Lihachev, 2008). Skinheads are perceived and portrayed as the only perpetrators and, consequently, the societal foundations of xenophobia are obscured.

16 An appalling example was published in the weekly Zerkalo Nedeli which addresses an educated public (Vedernikova, 2008). 
Right-wing groups and their supporters, as well as the lack of political correctness among some established politicians, have their basis in society. Under the surface of a peaceful society there is a breeding ground for right-wing violence. Ukrainian society does not seem prepared to welcome and integrate non-Slavic people, and social distance from other nationalities has been growing since 1991 (Panina, 2005a). Eastern Slavs (Ukrainians, Russians, Belarusians) are tolerated, while 'historical' neighbours such as Poles, Moldovans, Jews and Crimean Tatars are accepted to a lesser degree. Groups which do not have 'historical' roots on the territory of present-day Ukraine are disliked. This is especially true of 'new' minorities, i.e. people from Africa or Asia. Refugees and asylum seekers are mostly perceived as illegal migrants and as a threat to public welfare and health (ECRI, 2008: 16). Some ethnic groups, such as Arabs or Chechens, are linked with violent conflicts and terrorism and are met with widespread disapproval (Panina, 2005b).

Again, concrete commitment and measures against racism and xenophobia are dominated and financed by IGOs and western governments, while Ukrainian NGOs are only slowly taking up the issue. Countermeasures taken by the Ukrainian state arouse the suspicion that they are addressed to and tailored for the international community, not Ukrainian society.

\section{Conclusion}

In conclusion, Ukraine is unable to cope with the societal and political consequences or fulfil its international obligations. In the field of refugee and asylum policy, the Ukrainian government has adopted a wait-and-see attitude - by expecting the EU to fund certain projects before taking measures itself. The Ukrainian government is certainly not free in choosing its policy goals, but it does not even implement those measures which have been agreed and adopted. Instead, it is the IGOs that turn out to be the most dynamic actors; refugee and asylum policy are almost entirely donor-driven. If funding ended, the local NGOs would cease to exist.

Both the Ukrainian government and the EU primarily focus on 'combating' undocumented migration. There is a growing trend towards the securitisation of migration policy - largely imported from an EU which emphasises justice and home affairs, while the willingness and the capacity for a humane treatment of asylum seekers lags behind. Migration policy will certainly not become a political priority in Ukraine, especially as the Ukrainian authorities consider the EU to be responsible for 'illegal' migrants. EU institutions, in turn, deem the Ukrainian authorities as too weak to devise and implement policy. But in so doing, they paralyse the government and relieve it of its legal and political responsibilities. To put it bluntly, the EU - partly via other IGOs - creates the policy field and defines, finances, supervises and partly implements the measures to be taken. The erected facades are readily interpreted as indicators which allow the classification of Ukraine as a 'safe third country'. However, the human rights situation for migrants and refugees in Ukraine remains precarious.

\section{References}

Amnesty International (2008) Ukraine: Government Must Act to Stop Racial Discrimination London. 
Amnesty International (2010) Ukraine: 'Put Deeds before Words': Deliver Human Rights for Ukraine London.

Andrysek, Oldrich and Tarja Rantala (2008) The Local Integration of Refugees in the Republic of Belarus, the Republic of Moldova and Ukraine. 'A Strategy for Action' Kyiv: Secretariat of the Söderköping/Cross-Border Co-operation Process.

Braichevska, Olena et al. (2004) Non-traditional Immigrants in Kyiv Washington.

Coynash, Halya (2008) In Defence of Redheads Charkiv.

ECRI (2008) European Commission against Racism and Intolerance. Third Report on Ukraine Adopted on 29 June 2007, Strasbourg.

Geiger, Martin (2007) 'Internationale Regierungsorganisationen und die Steuerung von Migration: die Ukraine im Vorfeld der Europäischen Union’ IMIS-Beiträge 32: 61-87.

Hammarberg, Thomas (2006) Report by the Commissioner for Human Rights Mr. Thomas Hammarberg on His Visit to Ukraine, 10-17 December 2006 Strasbourg.

Human Rights First (2008) Ukraine. 2008 Hate Crime Survey New York.

Human Rights Watch (2005) Ukraine: On the Margins. Rights Violations against Migrants and Asylum Seekers at the New Eastern Border of the European Union New York: Report 17, 8.

ICPS (2005) Readmission Treaty Is Unlikely to Make Ukraine a Migration Buffer of the EU Kyiv: International Centre for Policy Studies 294.

ICPS and IPA (2006) Ukraine's Policy to Control Illegal Migration White Paper, Kyiv/ Warsaw: International Centre for Policy Studies/Institute for Public Affairs.

Knelangen, Wilhelm (2007) 'Nachbarn in Sicherheit, Freiheit und Recht? Inneres und Justiz: Ambivalenzen der ENP' Osteuropa 57(2-3): 257-272.

Kokhan, Halyna (2007) 'Die neue Visaregelung zwischen der Ukraine und der EU' Ukraine-Analysen 32: 2-3.

Kotnyuk, Yurii (2008) 'Migratsionnaya Sluzhba: Bor'ba Za Podchinenie' Zerkalo Nedeli 13-19 September.

Lihachev, Vyacheslav (2008) 'Antisemitizm i Ksenofobiya v Ukraine' Khronika I Kvartal (Yanvar'-Mart) www.kngu.org/KongrUkr/2008-03/likh-01-03-2008.html [last accessed: 22 January 2011].

Lihachev, Vyacheslav (2010) Prestuplenniya Na Pochve Nenavisti v Ukraine 2009: Provodim Itogi http://www.xenodocuments.org.ua/article/1799 [last accessed: 22 January 2011].

Manukjan, Vjačeslav (2008) V Bor'be s 'Etničeskoj Prestupnost'ju' - Etničeskij Profajling Nedopustim! Charkiv.

Oliynyk, Natalia (2006) Ukraine as a Transit Country for Irregular Migrants Conference Paper: School on Euro-Mediterranean Migration and Development, Florence. 
Panina, Nataliya (2005a) 'Faktory Natsional'noi Identichnosti, Tolerantnosti, Ksenofobii i Antisemitizma v Sovremennoi Ukraine' Sotsiologiya: Teoriya, Metody, Marketing 4: 26-45.

Panina, Nataliya (2005b) Sotsiologicheskii Monitoring. Ukrainskoe Obshchestvo 1994-2005: God Pereloma Kyiv.

Pribytkova, Irina (2007) 'Regular and Irregular Migration in Ukraine, Belarus and Moldova, 2004-2006' in Cross-Border Co-operation/Söderköping Process (Ed.): Migration Trends 2004-2006 Söderköping Process Countries Kyiv: 5-33.

Pylynskyi, Yaroslav (2008) Country Report Ukraine: Clandestino, Undocumented Migration. Counting the Uncountable. Data and Trends across Europe.

Ryzhuk, Lyudmila (2009) 'Migratsionnaya Sluzhba Ukrainy: Chetvertaya Popytka. Poslednyaya Li?’ Zerkalo Nedeli 12-18 September.

Söderköping Process (2008a) Asylum Seekers and Refugees Kyiv: Söderköping Process http://soderkoping.org.ua/page12484.html [last accessed: 22 January 2011].

Söderköping Process (2008b) Illegal Border Crossing Kyiv: Söderköping Process http://soderkoping.org.ua/page21107.html [last accessed: 22 January 2011].

Speer, Marc (2010) 'Die Ukraine als migrantisch genutztes Transitland' in: Sabine Hess and Bernd Kasparek (Eds.): Grenzregime. Diskurse, Praktiken, Institutionen in Europa Berlin: 57-72.

Uehling, Greta (2004) 'Irregular and Illegal Migration through Ukraine' International Migration 42(3): 77-109.

UNHCR (2007) UNHCR Position on the Situation of Asylum in Ukraine in the Context of Return of Asylum Seekers Geneva.

Vedernikova, Inna (2008) ‘Kiev: Rai Dlya Nelegalov?’ Zerkalo Nedeli 7-13 June.

Vobruba, Georg (2007) 'Expansion ohne Erweiterung. Die EU-Nachbarschaftspolitik in der Dynamik Europas' Osteuropa 57(2-3): 7-20.

Zimmer, Kerstin (2007) 'Time of the Migrants' Transitions Online 18 January.

Zimmer, Kerstin (2009) 'The Role of Ukraine within the European Migration System' in: Juliane Besters-Dilger (Ed.): Ukraine on Its Way to Europe. Interim Results of the Orange Revolution Frankfurt am Main, pp. 159-176.

Zimmer, Kerstin (2010) 'Abgründe und ihre Gründe. Fremdenfeindlichkeit und rechte Gewalt’ Osteuropa 60(3): 443-460. 